\title{
MEMPERTIMBANGKAN KUALITAS DATA KUALITATIF WAWANCARA PADA PARTISIPAN YANG MENGALAMI KESULITAN DALAM MENJELASKAN PENGALAMAN SECARA DETAIL
}

\author{
Musdalifah Dachrud \\ Institut Agama Islam Negeri Manado, Manado, Indonesia \\ musdalifahdachrud@yahoo.com
}

\begin{abstract}
This paper discusses the constraints and challenges that may arise when conducting qualitative interviews with people with language disabilities or the weak elderly who have difficulty explaining in detail about their experiences. The literature on qualitative research seems to assume that good quality qualitative interviews consist of long and unbroken narratives. This ideal includes specific requirements for research participants. Qualitative studies including weak elderly people or people with disabilities in communication will be disadvantaged by biased samples or vague descriptions. Strategies to maximize the quality of interview data, such as larger samples and more varied samples, require an investment of sufficient time to build a "rapport approach" in interview situations, repeated interviews, special interview techniques, and the incorporation of interviews and observations - participant observation is suggested.
\end{abstract}

Keywords: Qualitative methods, qualitative interviews, interviews, stroke sufferers, elderly (elderly) are weak

Abstrak. Tulisan ini membahas kendala-kendala dan tantangan-tantangan yang mungkin timbul ketika melakukan wawancara kualitatif dengan penyandang cacat bahasa atau lansia lemah yang mengalami kesulitan menjelaskan secara detil mengenai pengalaman-pengalaman mereka. Literatur-literatur tentang penelitian kualitatif tampaknya mengasumsikan bahwa wawancara kualitatif yang berkualitas baik terdiri dari narasi yang panjang dan tidak terputus. Hal ideal ini mencakup persyaratanpersyaratan khusus pada partisipan-partisipan penelitian. Kajian kualitatif termasuk lansia lemah atau orang yang cacat dalam berkomunikasi akan dirugikan dengan sampel yang bias atau deskripsi yang tidak jelas. Strategi-strategi untuk memaksimalkan kualitas data wawancara, seperti sampel yang lebih besar dan sampel yang lebih bervariasi, membutuhkan investasi waktu yang cukup untuk membangun "pendekatan awal/rapport" dalam situasi wawancara, wawancara berulang, teknik wawancara khusus, dan penggabungan wawancara dan pengamatan-pengamatan partisipan disarankan.

Kata Kunci: Metode kualitatif, wawancara kualitatif, wawancara, penderita stroke, lanjut usia (lansia) lemah 


\section{Pendahuluan}

Wawancara penelitian kualitatif adalah metode pengumpulan data klasik dalam studi-studi kualitatif. Wawancara penelitian kualitatif merupakan metode yang sangat disukai oleh para peneliti kualitatif. ${ }^{1}$ Ini mungkin karena wawancara penelitian kualitatif menjadi metode yang paling efisien dan kuat untuk menghasilkan teks-teks tentang pengalaman-pengalaman orang yang bukan diri mereka sendiri dan bukan pada diri mereka, menghasilkan teks-teks seperti itu. Wawancara penelitian kualitatif memiliki beberapa kekuatan yang menjelaskan popularitas dan kegunaannya, termasuk tingkat kontrol peneliti, kemungkinan untuk membangun hubungan yang baik dan percakapan antara peneliti dan partisipan, serta komitmen yang dibatasi dan terbatas pada sebagian dari orang yang diwawancarai. $^{2}$ Namun, ada kriteria tertentu yang harus dipenuhi jika metode ini digunakan untuk menghasilkan data yang berkualitas baik. Idealnya, dalam wawancara kualitatif memiliki narasi panjang dan tak terputus. ${ }^{3}$ Tingkat signifikansi dan pentingnya temuantemuan dan kesimpulan-kesimpulan penelitian kualitatif tergantung pada kualitas ketersediaan data tekstual, sehingga hal ini menjadi isu sentral bagi para peneliti kualitatif.

1 J. A. Holstein \& Gubrium, J. F. Inside interviewing: New lenses, new concern, In J. A. Holstein \& J. F. Gubrium (Eds), Inside interviewing new lenses, new concerns (Thousand Oaks: Sage Publications. 2003), (pp. 3-30).

2 S, Kvale, Det kvalitative forskningsintervju (The qualitative research interview) (2 ed). (Oslo: Gyldendal Akademisk, 2001)

${ }^{3}$ Holstein \& Gubrium, Op.Cit
Beberapa situasi dan kelompok yang diwawancarai menimbulkan berbagai tantangan dan ancaman yang lebih dari orang lain dalam hal data tekstual kualitatif yang dihasilkan. Tulisan ini mengambil rujukan pada pengalamanpengalaman dari penelitian yang melibatkan lansia lemah dan pasien yang menderita stroke, untuk menggambarkan beberapa isu penting bahwasanya para peneliti kualitatif harus menghadapi isu tersebut ketika melakukan penelitianpenelitian kualitatif wawancara dengan para pastisipan yang mengalami kesulitan dalam memberikan deskripsi yang kaya dan tidak terputus dari pengalamanpengalaman mereka. Pertama, dilakukan pemeriksaan pada kriteria-kriteria untuk data kualitatif yang dianggap wajib untuk mengamankan data yang berkualitas tinggi. Kedua, mendiskusikan kebutuhan dari situasi wawancara itu sendiri. Kemudian dilanjutkan dengan menyoroti ancaman dan tantangan tertentu yang mungkin timbul ketika mewawancarai orang-orang yang memiliki alasan-alasan yang berbeda, yang memiliki kesulitan dalam menyampaikan pengalaman yang panjang dan tidak terputus serta persyaratan-persyaratan ini berdampak pada para peneliti kualitatif. Akhirnya, berbagai strategi diusulkan untuk memaksimalkan kualitas data tekstual dalam penelitian-penelitian yang melibatkan partisipan yang kurang aktif dan kurang pandai berbicara dalam wawancara kualitatif.

\section{Kriteria Data Kualitatif}

Kriteria mendasar dari setiap penelitian kualitatif adalah data yang rinci dan penjelasan mendalam dari suatu fenomena. Bagi peneliti, dalam usaha 
mendapatkan data tekstual yang kaya dan menghasilkan deskripsi serta interpretasi kualitatif maka data harus memenuhi kriteria tertentu tersebut. Pertama, data harus dekat dengan pengalaman manusia yang sebenarnya terkait dengan fenomena atau situasi yang diteliti. Hal ini biasanya berarti bahwa data dihasilkan dari partisipan yang benar-benar mengalami pengalaman. ${ }^{4}$ Kedua, data kualitatif merupakan data yang diharapkan kaya, deskripsi rinci dari pengalaman, termasuk tindakan, perasaan, reaksi dan pikiran sebagaimana yang dialami oleh partisipan. ${ }^{5}$ Untuk menangkap variasi dalam pengalamanpengalaman pada orang-orang yang telah mengalami fenomena tertentu atau situasi yang bersangkutan, data harus memenuhi persyaratan variasi maksimum. ${ }^{6}$ Akhirnya, dalam kebanyakan penelitian kualitatif wawancara, tampaknya telah menjadi persepsi bahwa data kualitatif yang dihasilkan tidak boleh "terkontaminasi" oleh pra-pemahaman peneliti, yang berarti bahwa pengalaman pribadi peneliti, pemahaman teoritis, hipotesis atau asumsi tentang dampak fenomena atau dampak situasi atas sifat dari "data" yang dihasilkan.7 Namun, literatur terbaru tentang wawancara kualitatif menunjukkan perubahan peran pewawancara menjadi suatu mitra dialog dan memiliki kontribusi terhadap teks

4 Ibid

${ }^{5}$ Kvale, Op.Cit

$6 \mathrm{~K}$, Malterud, Kvalitative metoder $i$ medisink forsking (Qualitative methods in medical research) (2 ed). (Oslo: Universitetsforlaget. 2003)

7 W, Moyle, Unstructured interviews: Challenges when participants have a major depressive illness (Journal of Advanced Nursing, 2002) 39 (3), 266-273 yang dikembangkan selama proses wawancara. $^{8}$

Kriteria-kriteria ini memberikan petunjuk bahwa data kualitatif yang diharapkan adalah data yang dapat memberikan gambaran secara kontekstual, bervariasi, detail dari pengalaman, tindakan dan persepsi si subjek yang menemukan fenomena atau situasi yang diteliti. Meskipun sebagian besar peneliti kualitatif setuju bahwa seseorang tidak bisa melakukan penelitian kualitatif dari sikap yang tidak teoritis netral, diharapkan bahwa teoriteori tidak membatasi data yang dihasilkan secara signifikan. Tergantung pada perspektif filosofis peneliti bahwa teori memainkan peranan yang berbeda dalam menghasilkan atau memproduksi data, dari yang dianggap penting mengenai perspektif analitis yang diperlukan sampai pada kepekaan terhadap fenomena juga panduan pengumpulan data, ${ }^{9}$ yang berpotensi membatasi pra-pemahaman yang harus dikontrol atau "dikurung" agar peneliti dapat menangkap persepsi dan pengalaman pra-reflektif. ${ }^{10}$ Terlepas dari sikap filosofis, bagaimanapun, kedekatan dengan pengalaman dan perspektif si subyek, dijelaskan dalam kata-kata mereka sendiri, umumnya dianggap karakteristik wajib data kualitatif,

${ }^{8}$ Holstein \& Gubrium, Op.Cit; Kvale, Op.Cit

9 J, Fog, med samtalen som udgangpunkt: Det kvalitatove forsningsinterview (Conservation as starting point. The qualitative research interview) (Kobenhavn: Akademisk Forlag, 1994), U.B, Lilleaas, Fra en kropp I ustand til kroppen I det modern (From a body out of order to the body in the modern), (Oslo: Oslo Universitet, 2003), U.B, Lilleaas, kroppslig beredskap som vane (Bodily alertness as habit), (Sosiologisk Tidsskrift, 2005)13, 183-198

10 M.S, McNamara, Knowing and doing phenomenology, 2005, 42(6), 695-704 
khususnya dalam ilmu keperawatan dan kesehatan. ${ }^{11}$ Pembentukan data yang memenuhi berbagai persyaratan ini, memberikan beberapa tantangan kepada situasi wawancara itu sendiri, yang akan kami bahas kemudian.

\section{Kriteria Kualitas untuk Wawancara Kualitatif}

Kvale (2001) telah menyoroti kompleksitas yang terlibat dalam melakukan wawancara kualitatif. Dalam pandangannya, wawancara kualitatif yang berhasil ditentukan oleh beberapa karakteristik, termasuk deskripsi yang spontan, kaya, rinci dan relevan dari yang diwawancarai dan sejauh mana pewawancara menindaklanjuti serta mendorong orang yang diwawancarai menjelaskan arti dari deskripsi yang diperlukan. Kvale (2001) menyatakan bahwa pertanyaan-pertanyaan pewawancara yang lebih pendek dan semakin panjang jawaban-jawaban si subyek semakin baik. Selain itu, wawancara yang ideal adalah sebagian besar ditafsirkan sepanjang wawancara, dan pewawancara mencoba untuk memverifikasi interpretasiinterpretasinya dari jawaban subjek dalam proses wawancara itu. Akhirnya, wawancara adalah "komunikasi itu sendiri" adalah cerita yang terkandung dalam dirinya sendiri yang hampir tidak memerlukan banyak tambahan deskripsi dan penjelasan. ${ }^{12}$

Kriteria yang dijelaskan di atas menggarisbawahi pentingnya menciptakan situasi wawancara dimana yang diwawancarai mampu menyediakan;

\footnotetext{
${ }^{11} \mathrm{~K}$, Malterud, Op. Cit

12 Kvale, Op.Cit
}

kebanyakan yang tanpa gangguan, artikulasi yang baik, gambaran lengkap dari fenomena yang diteliti. Peran pewawancara disarankan sebisa mungkin pasif dan tidak mengganggu dalam pembentukan data, hanya memfasilitasi si pencerita dan mengamankan klarifikasi deskripsi dan interpretasi bila diperlukan. Persyaratan ini tercermin dalam kriteria yang baru-baru ini dilembagakan oleh jurnal penelitian juga, misalnya Petunjuk untuk Penulis; Jurnal Pengembangan Perawatan dan Jurnal Keperawatan Klinis, di mana jurnal tersebut mengharapkan kiranya wawancara fenomenologis menjadi terstruktur agar konsisten dengan desain fenomenologis.

Kunci pada situasi wawancara yang ideal, di mana pewawancara adalah "pasif" dan mengajukan sesedikit mungkin pertanyaan, memberikan beberapa persyaratan kepada partisipan dalam studi wawancara kualitatif, merupakan isu yang jarang tercermin dalam laporan penelitian kualitatif. Sebagian besar, persyaratan ini dirumuskan secara implisit dengan cara para peneliti menggambarkan kriteria inklusi mereka. Biasanya, mereka mencakup (a) menjadi anggota populasi atau kelompok yang diteliti, (b) memiliki kemampuan menggambarkan pengalaman dengan fenomena atau situasi secara fokus, (c) berada di negara yang memandang penting kesehatan yang mengijinkan partisipan dalam penelitian, dan (d) bersedia berbagi pengalamannya sendiri. Masing-masing kriteria mencakup masalah-masalah yang kompleks dalam hal menjadi "yang memenuhi syarat" untuk berpartisipasi dalam studi kualitatif. 
Pertanyaan terkait dengan keanggotaan partisipan, misalnya, tidak selalu merupakan masalah sederhana. Ini mencakup setidaknya dua pertanyaan yang terpisah, pertama mendefinisikan populasi penelitian, termasuk membedakannya dari populasi terkait, dan kedua, memastikan bahwa sampel yang diambil mencerminkan pengalaman dari populasi penelitian. Kebanyakan laporan penelitian kualitatif menggambarkan populasi atau kelompok belajar cukup secara umum. Pada penelitian kami, misalnya, fokus pada pengalaman pribadi setelah mengalami stroke otak, partisipan biasanya digambarkan sebagai "pasien yang telah menderita stroke" atau agak lebih terbatas "pasien yang pertama kali kena stroke" atau "wanita lansia yang baru saja mengalami stroke pertama kali".13 Sebuah tinjauan penelitian kualitatif baru-baru ini dalam literatur keperawatan, berfokus pada pengalaman bagaimana dampak stroke pada kehidupan penderita stroke, menunjukkan bahwa kebanyakan studi yang dipublikasikan tidak membedakan antara orang yang baru saja mengalami stroke dengan orang-orang yang tinggal bersama penderita stroke selama bertahun-tahun dalam hal kriteria inklusi dan dalam analisis pengalaman, ${ }^{14}$ meskipun ada alasan untuk percaya

13 G, Eilertsen, Alt er som for, men ingenting er som det var, Gamlekvinners opplevelser ev livet etter hjerneslaget ("Everything is the same, but nothing is what it used to be" *old "women's experiences of life after a stroke). Institute of Nursing and Health sciences, Faculty of Medicine, University of Oslo, 2005; Kvigne \& Kirkevold, 2003; K, Kvigne, Kirkevold \& Gjengedal, Fighting back "struggling to continue life and preserve the self following a stroke, Health Care for Women International, 2004, 25(4), 370-387 14 Ibid bahwa ini tidak selalu anggota "kelompok yang sama". Pengalaman awal setelah stroke pertama kali mungkin sangat berbeda dengan penderita stroke yang sudah lama, menunjukkan bahwa mempertimbangkan mereka sebagai anggota dari kelompok yang sama mungkin menutupi, bukan mengungkap, pengalaman tertentu pada tahap yang berbeda setelah mengalami stroke. ${ }^{15}$ Ini mencerminkan kenyataan bahwa memberikan perhatian dekat dengan definisi dari anggota kelompok atau populasi adalah penting untuk mendapatkan data mendalam yang memadai dan relevan yang mungkin patut disintesiskan.

Kemampuan

untuk menggambarkan pengalaman sebagian besar diasumsikan jika partisipan secara kognitif utuh, berbicara bahasa peneliti dan tidak menderita dari segala cacat kemampuan berbahasa, seperti afasia. Namun, Mozley dkk. (1999) menemukan bahwa orang dengan gangguan kognitif mampu membuat pernyataan yang valid tentang bagaimana mereka mengalami kualitas hidup mereka. Philpin, Yordania dan Gugur (2005) telah merefleksikan asumsi tak berdasar dalam penelitian mereka sendiri pada pasien PEG, dan diterangi beberapa kesulitan yang muncul dari kegagalan sampai pada mempertimbangkan dengan hati-hati masalah komunikasi antara partisipan dalam studi kualitatif sebelum memulai penelitian.

Kondisi kesehatan mengacu pada fakta bahwa situasi wawancara tidak akan mengancam stabilitas atau perkembangan kondisi penyakit pasien. Kesediaan untuk

\section{Ibid}


berpartisipasi mengacu pada persetujuan dan hal itu lebih berkaitan dengan persyaratan etika penelitian daripada kriteria inklusi yang menentukan populasi yang diteliti.

Demikian pula untuk sebagian besar studi wawancara kualitatif lainnya, kami merumuskan kriteria inklusi berikut dalam sebuah penelitian perkembangan lansia terbaru seperti yang dijelaskan oleh penghuni jompo yang mentalnya bagus. ${ }^{16}$ Partisipan harus 65 tahun atau lebih, dapat memahami dan membaca bahasa Norwegia, dapat berkomunikasi dan memberikan persetujuan, tinggal secara permanen di sebuah panti jompo selama sedikitnya dua bulan dan dianggap mampu menyelesaikan wawancara dan tertarik dan bersedia untuk berbicara tentang situasi mereka. Mereka tidak harus gila, benar-benar tertekan atau bingung.

Kriteria inklusi dan eksklusi ini fokus pada eksternal, tujuan karakteristik partisipan dalam penelitian. Kriteria tersebut tentunya dapat berdampak pada kemampuan responden menjadi partisipan aktif dalam wawancara kualitatif. Namun, memenuhi kriteria ini tidak menjamin pembentukan data kualitatif yang kaya dan relevan. Merefleksikan kriteria yang dimaksud dalam diskusi di atas, menjadi bukti bahwa mereka "menyembunyikan" persyaratan implisit yang mana kita sebagai peneliti kualitatif menganggap demikian, tetapi yang tidak secara

16 A, Bergland \& Kirkevold, "Residentcaregiver relationships and thriving among nursing home residents." Research in Nusing \& Health, 2005, 38(5), 365-375,"Thriving in nursing homes in Norway: Contributing aspects describes by residents." International Journal of Nursing Studies, 2006, 43(6), 681-691. eksplisit dinyatakan. Dalam sebuah artikel terbaru, Kvigne, Gjengedal dan Kirkevold (2002) membahas tiga persyaratan implisit yang diharapkan akan dipenuhi oleh partisipan dalam studi fenomenologis, tetapi yang kami percaya relevan dalam penelitian wawancara yang paling kualitatif. Mereka memasukkan partisipan "terbuka" pada pengalaman mereka, bahwa mereka memiliki kemampuan untuk mempertahankan fokus pada fenomena atau situasi dari waktu ke waktu dan bahwa mereka memiliki kompetensi narasi yang diperlukan untuk memberikan laporan lengkap, koheren dan terstruktur secara logis berdasar pada pengalaman mereka.

Hal yang ideal dari "keterbukaan pada pengalaman" mengacu pada kemampuan partisipan untuk secara sadar memahami dan merefleksikan pengalamannya sendiri dengan fenomena atau situasi yang bersangkutan. Ini mungkin sebuah tantangan yang mungkin bukan "sikap alami" partisipan dalam menghadapi dunia mereka. ${ }^{17}$ Ini memerlukan usaha mental yang cukup besar untuk menguraikan persepsi dan pengalaman terkait dengan fenomena yang menarik bagi peneliti dari "aliran kehidupan" partisipan.

Kemampuan

untuk mempertahankan fokus pada fenomena dan/atau situasi dari waktu ke waktu mengacu pada persyaratan seperti memori dan kemampuan untuk berkonsentrasi. Kompetensi "narasi" mencakup kemampuan untuk

17 Kvigne, K., Kirkevold \& Gjengedal, Gaining access to the life-world of women suffering from stroke: Methodological Issues in empirical phenomenological studies, Journal of Advances Nursing, 2002, 40(1), 61-68 
menggambarkan pengalaman seseorang secara rinci dan logis, untuk memberikan rincian lebih lanjut jika diperlukan, kemampuan untuk bergerak bolak-balik dari masa sekarang ke masa lalu, dan akhirnya kemampuan untuk memahami minat dan kebutuhan tertentu pewawancara dalam situasi wawancara. ${ }^{18}$

Persyaratan yang dibahas di atas cukup menuntut dan persyaratan tersebut tidak dapat selalu dianggap berhubungan dengan semua partisipan wawancara kualitatif. Pengalaman kami dengan lansia lemah dan pasien yang menderita stroke menjelaskan bahwa persyaratan ini tidak selalu ada di partisipan yang memenuhi syarat sesuai kriteria inklusi kami, menyoroti isu-isu yang perlu dipertimbangkan dengan hati-hati, ketika merencanakan penelitian wawancara kualitatif. Hal-hal ini akan dibahas berikutnya.

\section{Tantangan-tantangan}

Ketika Mewawancarai Partisipan yang Kesulitan dalam Memberikan Rincian yang Dapat Dipertanggungjawabkan.

Seperti diuraikan di atas, kualitas teks atau data yang dihasilkan dalam wawancara kualitatif tergantung pada partisipan individu, sampel dan situasi wawancara yang sebenarnya. Secara keseluruhan, kriteria kualitas ini menghasilkan gambaran implisit partisipan dalam penelitian wawancara kualitatif karena cukup sehat, banyak akal dan artikulasinya jelas. Partisipan dengan kesehatan lemah dan/atau cacat dalam berkomunikasi bisa gugur dari persyaratan-persyaratan $\quad$ ini. ${ }^{19}$ Kami

18 Ibid

19 B. R, Domarad \& Buschmann, M.T, Interviewing Older Adults: Increasing the credibility menemukan dalam penelitian kami, lansia lemah dan penderita stroke dimana beberapa isu berkaitan dengan kondisi kesehatan mereka berdampak signifikan pada situasi wawancara, percakapan dan kemampuan partisipan dalam menyampaikan deskripsi rinci pengalaman mereka.

Berbeda dengan yang lebih muda, partisipan yang lebih sehat, yang sering dilaporkan menikmati kesempatan menggambarkan situasi mereka yang mendalam, ${ }^{20}$ lansia lemah sering mudah lelah, dan mungkin kurang mampu atau kurang terbiasa memberikan deskripsi rinci situasi mereka. Masalah sensorik (gangguan pendengaran atau penglihatan), masalah konsentrasi dan kesulitan bahasa secara signifikan dapat mengurangi kemampuan mereka menghasilkan narasi yang tanpa gangguan dari situasi mereka. ${ }^{21}$

Tiga potensi ancaman terhadap pembentukan data yang kaya harus sebagai pertimbangan kehati-hatian ketika merencanakan penelitian wawancara kualitatif di mana lansia lemah dan orang dengan keterbatasan komunikasi dilibatkan. Satu ancamannya adalah ancaman dalam memperoleh contoh yang bias, atau lebih tepatnya sebuah "sampel elit", yang dapat mengakibatkan gambar yang tidak lengkap dari fenomena/situasi yang bersangkutan. Untuk menjamin kualitas wawancara individu, tampaknya masuk

of interview data, Journal of Gerontological Nursing, 1995, 21(9), 14-20

20 S, Reinharz \& Chase, "Interviewing women," In J.A Holstein \& J.F Gubrium (Eds), Inside interviewing new lenses, new concerns, Thousand Oaks: Sage Publication, 2003, (pp. 73-90))

21 Kvigne et al, Op.Cit, Wenger, 2003; Barat, Bondy \& Hutchinson, 1991) 
akal menambah hanya partisipan yang dapat memberikan deskripsi yang kaya dari situasi dan pengalaman mereka. ${ }^{22}$ Kebanyakan peneliti mencoba mengikuti rekomendasi ini. Namun, hal ini dapat menyebabkan hanya subyek yang paling artikulatif yang akan direkrut untuk penelitian. $^{23}$ Ini dapat mengancam validitas penelitian, dengan membentuk gambar miring atau tidak lengkap dari fenomena penelitian, di mana pengalaman dan persepsi para wakil partisipan yang artikulasinya kurang akan ditinggalkan. Hal ini pada gilirannya mengancam kebutuhan variasi maksimal. ${ }^{24}$ Dalam sebuah penelitian lembaga jaringan sosial lansia, Powers tidak mengikut sertakan orang tua dengan keterbatasan fisik, keterbatasan kognitif dan keterbatasan komunikasi, ${ }^{25}$ sementara menurut West et al akan sangat relevan untuk menjadi salah satu partisipan, karena institusi tersebut adalah kelompok paling tidak mampu bersosialisasi dan mempertahankan dukungan sosial, dan karena itu, menjadi kepentingan khusus untuk mengeksplorasi jaringan sosial di sebuah institusi. ${ }^{26}$

Menghindari masalah ini dengan memasukan kelompok partisipan yang lebih luas dapat menyelesaikan ancaman ini ke validitas, tapi menyebabkan masalah kualitas yang berbeda, yaitu

22 Kvale, Op.Cit

${ }^{23} \mathrm{M}$, Sandelowski, The problem of rigor in qualitative research, Advances in nursing sciences, 1986, 8(3), 27-37;. Barat et al, 1991

${ }^{24} \mathrm{~K}$, Malterud, Op.Cit

25 B.A Powers, Social Network, social support, and elderly institutionalized people, Advances in Nursing Science, 10 (2), 40-581988)

$26 \mathrm{M}$, West et al, Interviewing Institutionalized Elders: Threats to Validity, Image the Journal of Nursing Scolarship, 1991, 23, 171176 pembentukan yang disebut "data tipis". Berikut contoh yang menggambarkan hal tersebut: 27

I : Apa yang Anda bicarakan dengan teman anda?

$\mathrm{R}$ : Berbagai hal

I : Seperti apa?

$\mathrm{R}$ : Berbagai hal

I : Apakah anak-anak datang hari ini?

$\mathrm{R}: \mathrm{Ya}$

I : Menurut Anda apa yang akan Anda lakukan?

R: Saya tidak tahu apa yang akan mereka lakukan hari ini

I : Apa yang sering mereka lakukan?

$\mathrm{R}$ : Berbagai hal

I : Apakah Anda ingat apa hal-hal itu?

$\mathrm{R}$ : Tidak

Dalam rasa frustrasi dan keputusasaan peneliti, peneliti mencoba mendorong orang yang diwawancarai (yang mungkin sama-sama frustasi) menguraikan pengalamannya, tentulah hal ini mendorong partisipan secara verbal berbicara dan secara mental sanggup berpartisipasi. Namun, hal ini akan menghalangi pengetahuan masuk ke dalam pengalaman orang-orang yang tidak memiliki ciri-ciri ini.

Demikian pula, dalam penelitian kami tentang perkembangan lansia di panti jompo ${ }^{28}$ kami mengalami beberapa kali bahwa sebagian penghuni memiliki masalah konsentrasi selama wawancara dan masalah untuk tetap fokus pada isuisu yang dibahas. Pengalaman itu menjadi tantangan bagi peneliti, yang harus memutuskan apakah perubahan yang

\footnotetext{
27 Ibid

${ }^{28}$ A, Bergland \& Kirkevold, Op.Cit
} 
mendadak di dalam narasi atau keraguan menyampaikan pesan penting dalam hal pengalaman, pemikiran dan makna dari orang yang diwawancarai atau apakah hal tersebut merupakan konsekuensi dari konsentrasi yang menurun atau penyimpangan memori. Kutipan berikut menggambarkan hal ini:

I : Apa yang kau lakukan sepanjang sore hari?

$\mathrm{R}$ : Menghabiskan waktu dengan putri saya.

I : Apakah dia sering mengunjungi Anda?

$\mathrm{R}$ : Dia mengunjungi saya setiap hari.

I : Anda beruntung. Dia mengunjungi Anda setiap hari.

R: Ya. (jeda). Tapi kemudian tidak seperti itu lagi, jadi saya datang ke sini. Pertama, saya berada di panti jompo lain. Itu adalah panti jompo yang bagus. Atau apa yang tepat untuk menyebutkannya....... Dan kemudian setelah itu saya ada di sini.

I : Kemudian Anda datang ke sini?

$\mathrm{R}$ : Ya, dan kemudian saya datang ke tempat ... rumah yang sama, tapi saya tidak tahu harus berkata apa (pembicaraan sangat lambat dan ragu-ragu).

Daripada mengeluarkan orang yang tidak memiliki kualifikasi sebagai partisipan dalam wawancara kualitatif, perlu dipertimbangkan bagaimana merencanakan dan melakukan penelitian wawancara kualitatif dengan mengatasi kesulitan atau gangguan lansia lemah dan orang dengan keterbatasan komunikasi untuk dibawa ke situasi wawancara.
Akhirnya, wawancara yang melibatkan lansia lemah dapat menimbulkan kesalahpahaman antara pewawancara dengan yang diwawancarai, karena perbedaan dalam hal kelompok, jenis kelamin dan generasi. $^{29}$ Penggunaan konsep dan istilah, misalnya, secara signifikan dapat berbeda antara generasi. ${ }^{30}$ Istilah kualitas hidup yang produktif (kualitas hidup) misalnya, jarang digunakan oleh lansia ${ }^{31}$ atau digunakan secara berbeda diantara para lansia dalam literatur penelitian. ${ }^{32}$ Demikian pula, kesediaan untuk mengungkapkan perasaan batin dan mendiskusikan secara sosial isu-isu sensitif atau konflik yang berbeda diantara generasi. Dalam pembahasan selanjutnya, kita akan melihat strategi memaksimalkan kekayaan data kualitatif yang melibatkan lansia lemah dan orang dengan keterbatasan komunikasi.

\section{Memaksimalkan Kualitas Data Ketika Wawancara dengan Lansia Lemah atau Pasien yang Cacat}

Lansia lemah dan kelompok rentan lainnya, yang mungkin memiliki kesulitan berpartisipasi dalam penelitian sesuai dengan kriteria dan persyaratan yang dijelaskan di atas, sering ditinggalkan untuk alasan validitas. Dari sudut

${ }^{29}$ Kvigne et al., Op.Cit

$30 \mathrm{M}$, Bondevik, Datasamling ved intervju: Betydningen av $a^{\circ}$ snake same $\operatorname{spra}^{\circ} \mathrm{k}$ (Datacollection by interviewing; the importanceof using a common language), Sykeplein, 1994, 82 (4), 2427; Barat et al, 1991)

31 J, Christophersen, Livskvalitet hos de svageste older: En undersogelse af tre plejehjem (quality of life in the weakest elders), (Kobenhavn: Aeldre Sagen, 1999)

$32 \mathrm{~F}$, Hendry \& McVittie, Is quality of life healthy concept? Measuring and understanding life experiences of older people, (Qualitative Health Research, 2004), 14 (7), 961-975 
pandang kami, bagaimanapun, itu adalah kewajiban sosial dari ilmu keperawatan dan ilmu kesehatan untuk menghasilkan lebih banyak pengetahuan tentang pengalaman dan persepsi pasien yang rentan untuk memberikan perawatan yang mengakomodasi kebutuhan dan harapan mereka. ${ }^{33}$ Hal ini memerlukan usaha sadar untuk memaksimalkan pembentukan data yang kaya, data deskriptif yang mencerminkan pengalaman dari kelompok pasien yang kurang pandai berbicara.

Dalam rangka memfasilitasi partisipasi lansia lemah dan orang cacat dalam penelitian kualitatif, perhatian harus diarahkan pada desain yang dipilih. Sebagai contoh, peneliti mungkin sebaiknya merencanakan memasukkan sampel yang lebih besar dan lebih bervariasi daripada hanya sekedar dinyatakan perlu, untuk mengamankan deskripsi yang kaya dalam jumlah keseluruhan materi, ${ }^{34}$ tetapi pada saat yang sama memungkinkan partisipan kurang dalam beberapa keterampilan dan kemampuan yang biasanya diperlukan. Hal ini memastikan gambaran yang memadai tentang pengalaman dan persepsi orang dengan sumber daya yang bervariasi dan kemampuan berbicara. Dalam penelitian kami tentang penghuni panti jompo lansia lemah ${ }^{35}$ dan pasien yang menderita stroke, ${ }^{36}$ kami

33 J, Reed \& Payton, Privilaging the voices of older service users: A methodoligal challenge. (Social Sciences in Health: International Journal of Research \& Practice, 1998), 4(4), 230-24; J.P Robinson, Managing Urinary incontinence in the nursing home: Residents' perspectives, ( Journal of Advances Nursing, 2000b)

34 West et al., Op.Cit

${ }^{35}$ A, Bergland \& Kirkevold, Op.Cit

36 Kirkevold, Op.Cit; Kvigne \& Kirkevold, Op.Cit;. Kvigne et al, Op.Cit menemukan bahwa beberapa partisipan yang memenuhi kriteria inklusi kami memiliki kesulitan memberikan narasi rinci yang dapat dipertanggungjawabkan tentang pengalaman mereka. Lainnya tidak memiliki masalah sesuai dengan harapan kami tentang deskripsi yang tidak terganggu dan detil. Meskipun menimbulkan kekhawatiran dalam hal kualitas data ini, kami menemukan bahwa "deskripsi tipis" dari beberapa partisipan kami, menghasilkan informasi penting ketika diposisikan bersama-sama dengan partisipan yang lebih bisa berbicara. Informasi itu, meskipun nilainya terbatas bila dilihat dalam isolasi, juga menguatkan serta memperoleh wawasan yang memenuhi syarat dari partisipan yang memiliki artikulisi yang lebih baik. Wawancara yang termasuk "kurang ideal" ini akan memberikan pada kami gambaran yang sempit mengenai pengalaman dibandingkan dari apa yang kami capai dengan memasukan mereka sebagai partisipan.

Di dalam "penelitian perkembangan lansia"37 sikap mental penghuni mengenai tinggal di panti jompo ditemukan menjadi aspek inti dari perkembangan lansia. Salah seorang penghuni "yang berbicaranya lebih bagus" menyatakan dengan jelas bahwa "sikap adalah hal yang utama". Pernyataan ini mendorong kami mencari pernyataan-pernyataan yang berkaitan dengan sikap penghuni di antara penghuni "yang kurang mampu berbicara". Kami menemukan bahwa beberapa penghuni menggambarkan fenomena ini meskipun tidak begitu eksplisit. Pernyataan seperti ini yang

\footnotetext{
${ }^{37}$ A, Bergland, Op.Cit
} 
berasal dari penghuni yang kurang mampu berbicara menggarisbawahi pernyataan yang dilontarkan dengan jelas dan dengan demikian menekankan bahwa sikap yang menentukan untuk perkembangan lansia adalah cocok dalam teks materi. ${ }^{38}$

Masalah yang terkait adalah situasi wawancara itu sendiri. Perhatian yang lebih harus diberikan pada perencanaan dan persiapan wawancara kualitatif, untuk mendukung pendekatan awal/rapport dan memfasilitasi deskripsi yang kaya dari orang yang diwawancarai. ${ }^{39}$ Hal ini sangat penting ketika merencanakan mewawancarai subyek yang mungkin memiliki kesulitan dalam berpartisipasi pada istilah yang sama dengan peneliti di dalam percakapan. Bagi lansia lemah dan partisipan dengan masalah komunikasi, berpartisipasi dalam wawancara mungkin mengancam dan menyebabkan perasaan tidak "untuk menjadi" pada situasi serta rasa tak berdaya. ${ }^{40}$ Agar peneliti mendukung individu dan berkontribusi terhadap rasa nyaman dalam situasi untuk partisipan, lebih banyak waktu dapat diberikan untuk membangun pendekatan awal/rapport dengan yang diwawancara.

Selain itu, wawancara harus dilakukan dengan menghindari kekurangan/cacat partisipan. Strategi yang terakhir tampaknya penting untuk mencegah penurunan harga diri partisipan, untuk menjaga pendekatan awal/rapport dengan orang yang diwawancara dan untuk mencegah

\footnotetext{
38 Ibid

39 Kvale, Op.Cit

40 B,R, Domarad \& Buschmann, Op.Cit;.
} Kvigne et al, Op.Cit

mundurnya partisipan dari penelitian. Perasaan rendah diri dan harga diri dapat menurunkan keyakinann individu dalam pesan-pesan mereka dan menyebabkan hilangnya pesan penting. ${ }^{41}$ Dalam penelitian kami mengenai perkembangan lansia di antara penghuni panti jompo ${ }^{42}$ penghuni laki-laki dengan afasia menjadi gelisah dan menunjukkan tanda-tanda merasa tidak nyaman ketika tidak mampu untuk menjawab pertanyaan dan dia tidak ingin melanjutkan wawancara. Khusus untuk lansia lemah dan orang dengan masalah komunikasi, peneliti yang menunjukkan bahwa peneliti memiliki banyak waktu, peneliti tertarik pada deskripsi partisipan dan peneliti menyatakan pengalaman orang yang diwawancarai sangat berharga adalah sangat penting. ${ }^{43}$

Untuk

menghindari

kesalahpahaman atau kurangnya komunikasi yang efektif karena perbedaan usia, jenis kelamin atau sosial budaya, peneliti kualitatif harus dengan hati-hati mempertimbangkan bagaimana pertanyaan yang diutarakan dan mana pertanyaan yang etis untuk diutarakan, menjaga integritas dan otonomi berpikir dari orang tua dan orang yang rentan. ${ }^{44}$ Tujuan wawancara kualitatif adalah akses ke perasaan dan pengalaman pribadi orang yang diwawancarai. ${ }^{45}$ Mewawancarai penghuni lansia lemah yg dapat mengekspresikan keinginan untuk

${ }^{41}$ Kvigne et al., Op.Cit
${ }^{42}$ A, Bergland \& Kirkevold, Op.Cit
${ }^{43}$ B, R, Domarad \& Buschmann, Op.Cit
${ }^{44}$ Ibid; C, Foss \& Ellefsen, De utydelige overtramp? Etiske utfordringer ved kvalitative studier (The invisible encroachments* ethical challengers in qualitative research). Va॰rd I Norden (Nursing Science and Research in the Nordic Countries, 2004), 24 (3), 48-51. 45 Ibid; Kvale, Op.Cit 
memiliki lebih banyak kesempatan berbicara dengan pendamping mereka, ${ }^{46}$ mungkin suatu keseimbangan antara mendorong keterbukaan tanpa membuat penghuni memberitahu lebih dari yang mereka ingin katakana. ${ }^{47}$ Memiliki orang yang menghabiskan waktu dan mendengarkan mereka dengan waktu yang cukup menghasilkan ekspresi lebih pribadi dari yang mereka rencanakan. Membiarkan partisipan mengontrol pengalaman dan perasaan pribadi mereka dan menyampaikan hal itu kepada peneliti adalah penting.

Dalam penelitian perkembangan lansia di panti jompo ${ }^{48}$ salah satu penghuni menyatakan bahwa perawatan yang diterima bervariasi tergantung pada siapa pendamping yang datang untuk menolongnya. Sebagai peneliti, kami sangat tertarik dengan pernyataan ini, karena berpotensi memiliki relevansi untuk topik kami tentang perkembangan lansia. Karena itu, kami mendorongnya untuk menguraikan hal ini, tetapi harus menghormati dia menolak untuk melakukan hal itu.

Sedikit perhatian ditujukan terhadap pentingnya perbedaan generasi atau jenis kelamin antara pewawancara dan yang diwawancarai. ${ }^{49}$ Namun, diakui bahwa pemahaman umum adalah penting untuk memfasilitasi komunikasi dan berbagi pikiran dan perasaan, khususnya dalam hal isu-isu sensitif. 50 Bondevik (1994) telah menyoroti perbedaan dalam cara" istilah" kualitas digunakan dan

${ }^{46}$ Liukkonen, Life in a nursing home for the frail elderly. Clinical Nursing Research, 4, 358372. 1995)

47 Foss \& Ellefsen, Op.Cit

${ }^{48}$ A. Bergland \& Kirkevold, Op.Cit

${ }^{49}$ Reinharz \& Chase, Op.Cit

50 Bondevik, Op.Cit dipahami di seluruh generasi. Generasi yang lebih tua menghubungan istilah kualitas dengan pakaian dan mebel, bukan dengan hubungan interpersonal. Untuk mengamankan informasi yang valid, Domarad dan Buschmann menyarankan kesesuaian jenis kelamin ketika membahas isu-isu sensitif dengan lansia.

\begin{tabular}{lcrr}
\multicolumn{1}{c}{ Dalam } & studi & kami & tentang \\
perkembangan & lansia & di & rumah \\
perawatan,51 & kami & mengalami
\end{tabular}
keuntungan dari observasi peserta gabungan dengan wawancara berulang. Dalam periode pengamatan lapangan,kami dapat membangun pendekatan awal dengan penghuni. Menghabiskan waktu yang lebih lama bersama-sama dengan penghuni dalam kehidupan sehari-hari mereka di panti jompo juga memberikan kontribusi terhadap pengalaman penghuni memiliki sesuatu yang penting untuk disampaikan. Datang ke situasi wawancara penghuni mengenal peneliti dan sepertinya lebih siap untuk menggambarkan pengalaman dan perasaan mereka mengenai fenomena. Wawancara berulang juga memberikan kesan bagi penghuni bahwa peneliti memiliki waktu dan pengalaman dan sudut pandang mereka dihargai. Jangka waktu pengamatan lapangan juga memberi kami wawasan tentang kehidupan sehari-hari penghuni di panti jompo dan membuat kami dapat memperkenalkan tema dan isu-isu selama wawancara yang hampir tidak dapat kami diskusikan. Dengan cara demikian, kami juga dapat memberikan contoh-contoh dan merujuk kembali ke situasi tertentu dari yang penghuni bisa gambarkan

\footnotetext{
${ }^{51}$ A, Bergland, Op.Cit; kirkevold , Op.Cit
} 
tentang pengalaman dan perasaan dan membahas tema wawancara.

Menggunakan strategi yang berbeda mendengarkan aktif, tanpa mengambil alih berbicara, adalah sangat penting dalam situasi wawancara yang melibatkan partisipan yang membutuhkan dukungan ekstra untuk menceritakan pengalaman mereka. Kami menemukan hal ini merupakan tantangan, sebagaimana yang diminta peneliti bertoleransi pada kediaman yang panjang, permulaan yang salah dan fakta bahwa informasi mungkin tidak tampak jelas dimengerti atau relevan dengan kepentingan peneliti. Jika partisipan memiliki kekurangan memori, menghindari pertanyaan yang mengekspos masalah ini dengan cara yang mengancam integritas orang tersebut adalah wajib. ${ }^{52}$ menganjurkan menggunakan strategi "mendengarkan suatu tema, menafsirkannya, dan menyatakannya dalam bentuk pertanyaan") ketika mewawancarai lansia lemah. Kami menggunakan strategi ini dalam penelitian kami di panti jompo seperti yang digambarkan berikut ini:

Peneliti (P):

Bisakah Anda menjelaskan apa yang Anda alami sebagai 'hari baik'?

Responden (R):

Ya, itu adalah 'hari baik' ketika mereka semua datang (tertawa).

P : 'Hari baik' adalah ketika Anda dikunjungi oleh keluarga Anda?

$\mathrm{R}$ : Ya, saya dapat hidup untuk waktu yang lama.

52 West et al, Op.Cithal.174)
Meskipun strategi ini dapat ditafsirkan sebagai "pertanyaan terkemuka" dan dengan demikian bertentangan dengan hal yang ideal dari yang diwawancarai yang berbicara secara bebas tentang pengalaman mereka, hal tersebut sesuai dengan pemahaman terbaru dari wawancara kualitatif sebagai teks yang dibuat di mana kedua pewawancara dan yang diwawancarai dipandang sebagai subyek aktif yang memberikan kontribusi. ${ }^{53}$ Dalam pengalaman kami, strategi ini tidak membatasi narasi partisipan. Sebaliknya, itu mendorong elaborasi lebih lanjut pengalaman dan pikiran mereka.

Menggunakan alat bantu yang berbeda atau isyarat saat mewawancarai lansia lemah dapat memfasilitasi ekspresi perasaan pribadi mereka. Wenger (2003) menyarankan menggunakan isyarat seperti foto anggota keluarga ketika wawancara berfokus pada masalah keluarga terkait atau alat jika fokusnya adalah pada kerajinan atau keterampilan tertentu. Dalam penelitian pengalaman lansia lemah tentang pindah ke panti jompo atau perawatan di rumah Reed dan Payton (1998) menggunakan fotografi dan peta jaringan selama wawancara untuk mengeksplorasi perasaan orang tua itu.

Dengan meminta orang tua memilih sebuah foto dari rumah mereka sebagai suvenir dan foto mana yang mereka akan ambil jika mereka diminta untuk membuat sebuah souvenir dari panti jompo, foto itu dapat menimbulkan perasaan orang tua dalam argumen mereka untuk pilihan foto-foto itu.

\footnotetext{
${ }^{53}$ Holstein \& Gubrium, Op.Cit; Kvale,
} Op.Cit 
Dengan menggambar peta jaringan bersama dengan orang tua sebelum masuk panti jompo atau perawatan di rumah dan setelah mereka tinggal di sana selama beberapa saat, para peneliti dapat membahas mengenai pengalaman kedekatan. ${ }^{54}$

Meskipun kemampuan untuk mempertahankan fokus pada fenomena atau situasi telah digambarkan sebagai hal yang esensial, ${ }^{55}$ pengakuan akan kenangan selama wawancara dengan lansia lemah juga ditekankan ${ }^{56}$. Robinson (2000b) menegaskan bahwa penghuni dapat menggunakan cerita atau episode dari kehidupan mereka sebelumnya untuk menggambarkan nilai-nilai penting kehidupan.

Dalam penelitiannya tentang bagaimana penghuni panti jompo yang dikelola oleh Incontinence ${ }^{57}$, salah satu penghuni mengatakan beberapa cerita yang menggambarkan pentingnya menjadi independen selama hidupnya dan menggarisbawahi perjuangannya untuk menjadi independen dalam hal toilet di panti jompo. Kami juga mengalami hal ini dalam penelitian kami tentang perkembangan lansia. Beberapa penghuni menceritakan tentang kehidupan mereka sebelumnya dan menggunakan ini sebagai "tolok ukur" ketika berbicara tentang pengalaman mereka mengenai perkembangan lansia di panti jompo. Mereka juga menggunakan episodeepisode kehidupan mereka sebelumnya untuk membuat kami melihat mereka

\footnotetext{
${ }^{54}$ Reed \& Payton, Op.Cit

${ }^{55}$ Kvigne et al., Op.Cit

${ }^{56}$ J, P. Robinson, 2000b, Op.Cit

57 J, P. Robinson, Managing urinanry
} incontinence in the nursing home: residents' perspectives. Journal of Advances Nursing, 31 (1), 68-77, 2000a sebagai lebih dari penghuni lemah yang tergantung. Meskipun mengakui periode kenangan mungkin kontras dengan idealnya "sebuah wawancara yang baik" di mana pewawancara dan yang diwawancarai erat dengan tema selama keseluruhan wawancara, penjelasan Robinson (2000b) mengenai tujuan kenangan selama wawancara dengan lansia lemah harus mengingatkan kami untuk menyadari tidak mengganggu cerita yang tidak segera tampak relevan dengan apa yang ada pada subjek.

Dalam studi perkembangan lansia di antara penghuni panti jompo, ${ }^{58}$ kami mengalami bahwa beberapa orang yang diwawancarai staminanya menurun karena masalah kesehatan. Hal ini mendesak kami untuk melakukan wawancara berulang untuk membahas masalah penelitian kami secara menyeluruh. Wawancara berulang juga memberikan kami kesempatan untuk mendiskusikan masalah yang kami alami saat wawancara sebelumnya yang tidak jelas. Dengan menyalin wawancara sebelum melakukan wawancara berikutnya, kami juga bisa membahas isu dan penafsiran kami dengan yang diwawancarai, sejalan dengan Reed dan Payton (1998), yang menegaskan bahwa kontak berkelanjutan membuat mereka terlibat dalam proses validasi dengan orang tua termasuk dalam penelitian mereka.

\section{Kesimpulan}

Termasuk dalam partisipan yang rentan, seperti lansia lemah dan pasien cacat, dalam penelitian kualitatif adalah kewajiban profesional dalam ilmu

\footnotetext{
58 Bergland \& Kirkevold, Op.Cit
} 
kesehatan bahkan jika mereka menimbulkan banyak tantangan dalam hal menghasilkan data sekaya "teks kualitatif' yang memenuhi persyaratan ideal penelitian kualitatif. Termasuk partisipan rentan dalam penelitian kualitatif mensyaratkan bahwa isu-isu peneliti yang terkait dengan pengambilan sampel, data atau pembentukan teks, dan peran kedua partisipan dan peneliti dalam menghasilkan teks-teks yang memadai mencerminkan fenomena atau situasi. Agar berhasil, para peneliti yang melibatkan lansia lemah dan partisipan rentan lainnya perlu mempertimbangkan kembali kecenderungan utama untuk lebih memilih pendekatan wawancara kualitatif mendalam yang tunggal, dengan beberapa informan utama terpilih yang tidak berbicara, yang bisa berbicara, yang berefleksi dengan baik dan berfungsi dengan baik dalam wawancara sosial. Sebaliknya, kita perlu mencari cara lebih beragam untuk menangkap pengalaman dan pikiran orang yang rentan, namun merupakan partisipan berharga yang mendasari penelitian kualitatif kita.

\section{Daftar Pustaka}

Bergland, A \& Kirkevold. 2005. "Residentcaregiver relationships and thriving among nursing home residents." Research in Nusing \& Health, 38(5), 365-375, "Thriving in nursing homes in Norway: Contributing aspects describes by residents." International Journal of Nursing Studies, 2006, 43(6), 681691.

Bondevik M. 1994. Datasamling ved intervju: Betydningen av $a^{\circ}$ snake same $\operatorname{spra}^{\circ} \mathrm{k}$ (Data-collection by interviewing; the importanceof using a common language). Sykeplein. 82 (4), 24-27; Barat et al, 1991

Christophersen, J. 1999. Livskvalitet hos de svageste older: En undersogelse af tre plejehjem (quality of life in the weakest elders), Kobenhavn: Aeldre Sagen

Domarad, B.R, \& Buschmann, M.T. 1995. Interviewing Older Adults: Increasing the credibility of interview data. Journal of Gerontological Nursing, 1995. 21(9), 14-20

Eilertsen, G. 2005. Alt er som for, men ingenting er som det var, Gamlekvinners opplevelser ev livet etter hjerneslaget ("Everything is the same, but nothing is what it used to be" *old "women's experiences of life after a stroke). Institute of Nursing and Health sciences, Faculty of Medicine, University of Oslo; Kvigne \& Kirkevold. 2003; K, Kvigne, Kirkevold \& Gjengedal, Fighting back "struggling to continue life and preserve the self following a stroke, Health Care for Women International, 2004, 25(4), 370387

Fog, J. 2003. med samtalen som udgangpunkt: Det kvalitatove forsningsinterview (Conservation as starting point. The qualitative research interview). Kobenhavn: Akademisk; Forlag. 1994. U.B, Lilleaas, Fra en kropp I ustand til kroppen I det modern (From a body out of order to the body in the modern). Oslo: Oslo Universitet. U.B, Lilleaas, kroppslig beredskap som vane (Bodily alertness as habit), (Sosiologisk Tidsskrift, 2005)13, 183-198 
C, Foss \& Ellefsen, 2004, De utydelige overtramp? Etiske utfordringer ved kvalitative studier (The invisible encroachments* ethical challengers in qualitative research). Va॰rd I Norden (Nursing Science and Research in the Nordic Countries), 24 (3), 48-51.

Holstein, J. A. \& Gubrium. 2003. J. F. Inside interviewing: New lenses, new concern, In J. A. Holstein \& J. F. Gubrium (Eds), Inside interviewing new lenses, new concerns, Thousand Oaks: Sage Publications

J.P. Robinson. 2000a. Managing urinanry incontinence in the nursing home: residents' perspectives. Journal of Advances Nursing, 31 (1), 68-77

2000b. Managing Urinary incontinence in the nursing home: Residents' perspectives. Journal of Advances Nursing

Kvale, S. 2001. Det kvalitative forskningsintervju (The qualitative research interview) (2 ed). Oslo: Gyldendal Akademisk

Kvigne, K., Kirkevold \& Gjengedal. 2002. Gaining access to the life-world of women suffering from stroke: Methodological Issues in empirical phenomenological studies, Journal of Advances Nursing, 40(1), 61-68

Kirkevold \& Gjengedal. 2004. Gaining access to the life-world of women suffering from stroke: Methodological Issues in empirical phenomenological studies, Journal of Advances Nursing

Liukkonen. 1995. Life in a nursing home for the frail elderly. Clinical Nursing Research, 4, 358-372.
Malterud, K. 2003. Kvalitative metoder $i$ medisink forsking (Qualitative methods in medical research) (2 ed). Oslo: Universitetsforlaget

McNamara M.S. 2005. Knowing and doing phenomenology. 42(6), 695-704

Moyle, W. 2002. Unstructured interviews: Challenges when participants have a major depressive illness Journal of Advanced Nursing. 39 (3). 266-273

M, Sandelowski. 1986. The problem of rigor in qualitative research, Advances in nursing sciences. 8(3), 27-37; . Barat et al, 1991

Powers, B.A. 1988. Social Network. social support and elderly institutionalized people. Advances in Nursing Science. 10 (2), 40-58

Reed, J \& Payton. 1998. Privilaging the voices of older service users: $A$ methodoligal challenge. Social Sciences in Health: International Journal of Research \& Practice. $4(4), 230-24$

Reinharz, S \& Chase. 2003. "Interviewing women," In J.A Holstein \& J.F Gubrium (Eds). Inside interviewing new lenses, new concerns. Thousand Oaks: Sage Publication. (pp. 73-90))

West $\mathrm{M}$, et al. 1991. Interviewing Institutionalized Elders: Threats to Validity. Image the Journal of Nursing Scolarship. 23, 171-176 